\title{
Shortcomings of Trials Assessing Antidepressants in the Management of Irritable Bowel Syndrome: A Critical Review
}

\author{
Sun Jung $\mathrm{Oh}^{1}{ }^{1}$, Will Takakura ${ }^{2}$ and Ali Rezaie ${ }^{2, *}$ \\ 1 Johns Hopkins Hospital, Baltimore, MD 21287, USA; soh51@jhmi.edu \\ 2 Cedars-Sinai Medical Center, Los Angeles, CA 90048, USA; Will.Takakura@cshs.org \\ * Correspondence: Ali.Rezaie@cshs.org; Tel.: +1-310-248-8711
}

Received: 16 July 2020; Accepted: 9 September 2020; Published: 11 September 2020

check for updates

\begin{abstract}
Irritable bowel syndrome (IBS) is a common disorder requiring complex, multidisciplinary management. Antidepressants are commonly used and recommended in guidelines for the treatment of patients with IBS. We assessed randomized controlled trials (RCTs) on antidepressants in patients with IBS, with specific attention to study design and data quality/reporting characteristics. Following a comprehensive search, data and RCT characteristics were systematically summarized. Fragility index, representing the number of positive "events" that the study relies on for its significance, was calculated. Eighteen RCTs were included. Overall, tricyclic antidepressants (TCAs), but not selective serotonin reuptake inhibitors (SSRIs), appeared to be efficacious in IBS. Eight studies reported on adverse events (AEs), which were significantly greater in patients receiving antidepressants versus placebo. The median (mean) fragility index of TCA trials was 0 (1.5). RCTs with positive results had significantly lower placebo rates $(20.8 \%)$ versus negative studies $(45.7 \% ; p<0.0001)$. RCTs exhibited limitations related to study design (sample size and blinding), data analysis (outcomes and placebo response), and data reporting (selective reporting of AEs and publication bias). Careful consideration of limitations of RCTs on antidepressants in IBS is warranted to formulate a safe and beneficial treatment regimen for patients with IBS.
\end{abstract}

Keywords: antidepressive agents; tricyclic antidepressants; irritable bowel syndrome; publication bias; healthcare quality assessment; serotonin reuptake inhibitors

\section{Introduction}

Irritable bowel syndrome (IBS) is characterized by recurrent abdominal pain associated with defecation and with alterations in stool frequency or form [1]. Patients affected by IBS also commonly experience bloating and abdominal distention. It is a common, chronic condition estimated to affect $11.2 \%$ of individuals worldwide [2]. IBS is further classified by the predominant stool form observed during $>25 \%$ of bowel movements: IBS with constipation (IBS-C), IBS with diarrhea (IBS-D), and IBS with mixed bowel habits [1]. Patients with IBS often have impairments in quality of life [3,4]. Indeed, the severity of IBS symptoms was shown to be associated with daily activity impairment [4]. The negative effects of IBS also extend into patients' professional lives. In a study of patients with IBS, $24.3 \%$ of employed patients had been absent from work during the previous week, and $86.8 \%$ had experienced a decrease in work productivity [4].

Patients with IBS often experience psychological comorbidities, such as anxiety and depression. A meta-analysis of 27 studies showed levels of anxiety (pooled standardized mean difference [SMD], 0.84; 95\% confidence interval (CI), 0.67-1.01; $p<0.001$ ) and depression (pooled SMD, $0.76 ; 95 \%$ CI, $0.62-0.90 ; p<0.001$ ) were significantly higher in adults with IBS compared with healthy controls [5]. 
However, it is unclear whether the high rate of depression among patients with IBS is part of the disease pathophysiology or a direct result of the chronic, relapsing, and debilitating nature of IBS [6]. Nevertheless, antidepressants have been used for $>40$ years and are recommended in societal guidelines for treatment of IBS patients with or without concomitant psychiatric disorders. The American College of Gastroenterology recommends tricyclic antidepressants (TCAs) for overall symptom improvement in IBS patients (recommendation: strong; quality of evidence: high) and also suggests selective serotonin reuptake inhibitors (SSRIs; recommendation: weak; quality of evidence: low) [7]. In contrast, American Gastroenterological Association guidelines give a conditional recommendation for TCAs (low quality of evidence) but conditionally recommend against SSRIs for IBS (low quality of evidence) [8]. Notably, none of the eight drugs that have received US Food and Drug Administration (FDA) approval for IBS (alosetron, eluxadoline, linaclotide, lubiprostone, rifaximin, plecanatide, tegaserod, and tenapanor) or European Medicines Agency (EMA)-approved drugs (eluxadoline and linaclotide) have antidepressant properties [9]. Low-grade inflammation, bile acid malabsorption, dysmotility, and gut microbiome dysbiosis have important roles in the etiology of IBS $[7,10,11]$. However, antidepressants have little modulatory effect on these factors [7].

Several meta-analyses and systematic reviews have been performed on the use of antidepressants in IBS, with the main focus on efficacy rather than the side-effect profile and trial data quality [12-14]. The current aim was to critically review the efficacy of antidepressants in IBS reported in clinical trials and comprehensively review the side-effect profile, quality of evidence, and strengths and weaknesses of the identified trials.

\section{Methods}

Relevant clinical studies and systematic reviews were identified by searching the PubMed and EMBASE databases from 1966 to 30 September 2019, for articles in any language, using the following search terms: "antidepressants," "tricyclic antidepressant," "selective serotonin reuptake inhibitor," "irritable bowel syndrome," "depression," "anxiety," and "comorbid." The risk of bias was assessed based on guidelines provided in the Cochrane Handbook for Systematic Reviews of Interventions [15] by recording the method used to generate the randomization schedule and conceal treatment allocation; whether blinding was implemented for participants, personnel, and outcomes assessment; what proportion of patients completed follow-up; whether an intention-to-treat analysis was extractable; and whether there was evidence of selective reporting of outcomes. Two investigators performed this assessment independently, and disagreements were resolved by consensus. Fragility index was calculated by converting the number of patients who were considered "non-responders" to "responders" in order for the $p$-value to become $>0.05$ using the Fisher's exact test.

\section{Efficacy of Antidepressants in IBS}

Twelve randomized controlled trials (RCTs) of TCAs and seven RCTs of SSRIs for IBS (Table 1) are commonly cited in meta-analyses and systematic reviews (referenced in $\geq 20$ articles, based on literature search [12-14,16-32]), and these 18 trials (one trial evaluated both a TCA and an SSRI) were published between 1978 and 2017 [33-50]. 
Table 1. Summary of clinical studies of antidepressants in patients with irritable bowel syndrome ${ }^{\text {a }}$

\begin{tabular}{|c|c|c|c|c|}
\hline $\begin{array}{l}\text { Study Design and } \\
\text { Patient Population }\end{array}$ & Treatment(s) & Key Endpoint ${ }^{b}$ & AEs Reported & Discontinuations \\
\hline & & TCAs & & \\
\hline Heefner JD, et al. [38] & $\begin{array}{l}\text { Desipramine }(n=22) \\
150 \mathrm{mg} / \mathrm{d} \text { for } 2 \mathrm{mo} \\
\text { PBO }(n=22)\end{array}$ & $\begin{array}{c}\text { Percentage of patients with self-reported improvement in } \\
\text { abdominal pain or discomfort at } 8 \text { wk: } \\
\text { ITT }(n=31): 85.7 \% \text { (12/14) desipramine vs. } 58.8 \%(10 / 17) \\
\text { PBO, } p>0.05\end{array}$ & Yes & $\begin{array}{c}\text { Desipramine: } \\
\text { - } n=8(36.4 \%) ; 3 \text { due to AEs } \\
\text { PBO: } \\
\text { - } n=5(22.7 \%) ; 1 \text { due to AEs }\end{array}$ \\
\hline Myren J, et al. [39] & $\begin{array}{l}\text { Trimipramine }(n=30) \\
25 \mathrm{mg} / \mathrm{d} \text { for } 28 \mathrm{~d} \\
\text { PBO }(n=31)\end{array}$ & $\begin{array}{l}\text { Improvement from baseline in patient-graded symptom } \\
\text { scores at } 4 \mathrm{wk} \text { : } \\
\text { ITT }(n=61): \sim 50 \% \text { improvement from baseline in } \\
\text { individual symptom scores in trimipramine and PBO } \\
\text { groups (significant in trimipramine group vs. PBO for } \\
\text { vomiting, sleeplessness, and depression) }\end{array}$ & No & NR \\
\hline Nigam P, et al. [41] & $\begin{array}{c}8 \text { combinations of } 3 \text { simultaneous } \\
\text { treatments ( } n=21 \text { per group): } \\
\text { A: amitriptyline } 12.5 \mathrm{mg} / \mathrm{d}+5 \mathrm{mg} \\
\text { chlordiazepoxide } \\
\text { a: dummy } \\
\text { B: hyoscine butylbromide } \\
\text { b: dummy } \\
\text { C: ispaghula husk } \\
\text { c: dummy }\end{array}$ & $\begin{array}{c}\text { Improvement in IBS symptoms at } 12 \mathrm{wk} \text { ( } n=168 \\
\text { [21 blocks of } 8 \text { patients): } \\
51.2 \% \text { with any "A" (amitriptyline) combination vs. } 23.8 \% \\
\text { any "a" (dummy) combination; } p<0.01\end{array}$ & Yes & NR \\
\hline Boerner D. [44] & $\begin{array}{c}\text { Doxepin }(n=42) \\
\text { PBO }(n=41)\end{array}$ & $\begin{array}{l}\text { Mean improvement (SD) from baseline in abdominal pain } \\
\text { at } 8 \text { wk: } \\
\qquad \begin{array}{c}-0.7 \text { (0.9) with doxepin }(n=40) \text { vs. }-0.4(1.0) \text { PBO }(n=39 ; \\
p<0.05)\end{array}\end{array}$ & Yes & $\begin{array}{c}\text { Doxepin: } \\
\text { - } n=2(4.8 \%) \\
\text { PBO: } \\
\text { - } n=2(4.9 \%)\end{array}$ \\
\hline Bergmann ML, et al. [43] & $\begin{array}{l}\text { Trimipramine }(n=19) \\
\operatorname{PBO}(n=16)\end{array}$ & $\begin{array}{l}\text { Global improvement at } 12 \text { wk: } \\
\text { trimipramine } 73.7 \%(14 / 19) \text { vs. PBO } 12.5 \%(2 / 16) ; p=\text { NR }\end{array}$ & No & $\begin{array}{r}\text { Trimipramine: } \\
\text { - } n=1(5.3 \%) \\
\text { PBO: } \\
\text { - } n=3(18.8 \%)\end{array}$ \\
\hline Vij JG, et al. [40] & $\begin{array}{l}\text { Doxepin }(n=25) \\
75 \mathrm{mg} / \mathrm{d} \text { for } 6 \mathrm{wk} \\
\text { PBO }(n=25)\end{array}$ & $\begin{array}{c}\text { Overall improvement } \geq 50 \% \text { of symptoms sustained for } \\
\quad 4 \text { wk after EOT: } \\
\text { ITT ( } n=44): 52.4 \% \text { with doxepin vs. } 21.7 \% \text { PBO; } p<0.05\end{array}$ & Yes & $\begin{array}{c}\text { Doxepin: } \\
\text { - } n=4(16.0 \%) ; 2 \text { due to AEs } \\
\text { PBO: } \\
\text { - } n=2(8.0 \%) ; 0 \text { due to AEs }\end{array}$ \\
\hline
\end{tabular}


Table 1. Cont.

\begin{tabular}{|c|c|c|c|c|}
\hline $\begin{array}{l}\text { Study Design and } \\
\text { Patient Population }\end{array}$ & Treatment(s) & Key Endpoint ${ }^{b}$ & AEs Reported & Discontinuations \\
\hline Drossman DA, et al. [33] & $\begin{array}{l}\text { Desipramine }(n=144) \\
\text { Initial dose: } 50 \mathrm{mg} / \mathrm{d} \text { for } 1 \mathrm{wk} \\
\text { Increase to } 100 \mathrm{mg} / \mathrm{d} \text { after } 1 \mathrm{wk} \\
\text { Increase to } 150 \mathrm{mg} / \mathrm{d} \text { after } 2 \mathrm{wk} \\
\operatorname{PBO}(n=71)\end{array}$ & $\begin{array}{c}\text { Mean (SE) composite score (treatment satisfaction, global } \\
\text { well-being, pain, health-related QOL) at wk } 12 \text { for } \\
\text { desipramine vs. PBO: } \\
\text { ITT }(n=201): 0.49(0.02) \text { vs. } 0.45(0.02) ; p=0.16 \\
\text { PP }(n=153): 0.55(0.02) \text { vs. } 0.48(0.02) ; p=0.03\end{array}$ & Yes & $\begin{array}{c}\text { Desipramine: } \\
\text { - } n=40(29.6 \%) ; 23 \text { due to AEs } \\
\text { PBO: } \\
\text { - } n=11(16.7 \%) ; 3 \text { due to AEs }\end{array}$ \\
\hline Talley NJ, et al. [35] & $\begin{array}{c}\text { Imipramine }(n=18) \\
\text { Initial dose: } 25 \mathrm{mg} / \mathrm{d} \\
\text { Increased to } 50 \mathrm{mg} / \mathrm{d} \text { after } 2 \mathrm{wk} \\
\text { PBO }(n=16)\end{array}$ & $\begin{array}{l}\text { Patients achieving adequate relief of IBS symptoms at last } \\
\text { wk of tx (up to } 12 \mathrm{wk}): \\
\text { ITT }(n=34): 100 \% \text { with imipramine vs. } 69.2 \% \text { PBO; } \\
p=0.80\end{array}$ & Yes & $\begin{array}{c}\text { Imipramine: } \\
\text { - } n=9(50.0 \%) \text {; due to AEs NR } \\
\text { PBO: } \\
\text { - } n=3(18.8 \%) \text {; due to AEs NR }\end{array}$ \\
\hline Vahedi H, et al. [34] & $\begin{array}{l}\text { Amitriptyline }(n=27) \\
10 \mathrm{mg} / \mathrm{d} \text { for } 2 \mathrm{mo} \\
\text { PBO }(n=27)\end{array}$ & $\begin{array}{c}\text { Mean total symptom score (baseline: AMI [2.5]; PBO [2.4]) } \\
\text { At } 4 \text { wk: } \\
\text { AMI: } 1.2 ; p=0.005 \text { vs. baseline } \\
\text { PBO, } 1.6, p=0.01 \text { vs. baseline } \\
\text { No significant between-group differences } \\
\text { At } 8 \text { wk: } \\
\text { AMI: } 0.5, p<0.001 \text { vs. baseline } \\
\text { PBO: } 1.6, p<0.005 \text { vs. baseline } \\
\text { Significant improvement with AMI vs. PBO }(p=0.01)\end{array}$ & Yes & $\begin{array}{c}\text { Amitriptyline: } \\
\text { - } n=2(7.4 \%) ; 1 \text { due to AEs } \\
\text { PBO: } \\
\text { - } n=2(7.4 \%) ; 1 \text { due to AEs }\end{array}$ \\
\hline Ghadir MR, et al. [42] & $\begin{array}{c}\text { Doxepin }(n=29) \\
\text { Nortriptyline }(n=29) \\
\operatorname{PBO}(n=29)\end{array}$ & $\begin{array}{l}8 \mathrm{wk}(n=75) \text { : } \\
\text { Abdominal pain and bloating improvement scores from } \\
\text { baseline significantly higher with doxepin vs. } \\
\text { nortriptyline }(p=0.001) \text { or vs. PBO }(p=0.01) ; \\
\text { improvement in diarrhea higher with nortriptyline vs. } \\
\text { doxepin or PBO }(p=0.02)\end{array}$ & No & - $\quad n=12(4$ in each group; $13.8 \%)$ \\
\hline Abdul-Baki H, et al. [36] & $\begin{array}{c}\text { Imipramine }(n=59) \\
25 \mathrm{mg} / \mathrm{d} \text { for } 12 \mathrm{wk} \\
\text { Optional doubling of dose at } \mathrm{wk} 2 \\
\text { PBO }(n=48)\end{array}$ & $\begin{array}{l}\text { Percentage of patients achieving global symptom relief at } \\
12 \text { wk: } \\
\begin{array}{c}\text { ITT }(n=107): 42.4 \% \text { with imipramine vs. } 25.0 \% \text { PBO, } \\
p=0.06 \\
\text { PP ( } n=56): 80.6 \% \text { with imipramine vs. } 48.0 \% \text { PBO; } \\
p=0.01\end{array}\end{array}$ & Yes & $\begin{array}{c}\text { Imipramine: } \\
\text { - } n=28(47.5 \%) ; 14 \text { due to AEs } \\
\text { PBO: } \\
\text { - } n=23(47.9 \%), 6 \text { due to AEs }\end{array}$ \\
\hline Agger JL, et al. [37] & $\begin{array}{l}\text { Imipramine }(n=70) \\
\text { Initial dose: } 10 \mathrm{mg} / \mathrm{d} \text { for } 1 \mathrm{wk} \\
\text { Increasing to } 25 \mathrm{mg} / \mathrm{d} \text { after } 1 \mathrm{wk} \\
\text { Increasing to } 75 \mathrm{mg} / \mathrm{d} \text { after wk } 2 \\
\text { PBO }(n=68)\end{array}$ & $\begin{array}{c}\text { Patient-rated overall improvement in health on CGI scale } \\
\text { at wk 13: } \\
\text { OR for improved outcome } \\
\text { ITT }(n=125): 3.3(95 \% \text { CI, } 1.6-6.8) ; p=0.001 \\
\operatorname{PP}(n=110): 3.8 \text { ( } 95 \% \text { CI, } 1.8-8.1) ; p=0.001\end{array}$ & Yes & $\begin{array}{c}\text { Imipramine: } \\
\text { - } n=8(11.4 \%) ; 4 \text { due to } \mathrm{AEs} \\
\text { PBO: } \\
\text { - } n=7(10.3 \%) ; 3 \text { due to } \mathrm{AEs}\end{array}$ \\
\hline
\end{tabular}


Table 1. Cont

\begin{tabular}{|c|c|c|c|c|}
\hline $\begin{array}{l}\text { Study Design and } \\
\text { Patient Population }\end{array}$ & Treatment(s) & Key Endpoint ${ }^{b}$ & AEs Reported & Discontinuations \\
\hline \multicolumn{5}{|c|}{ SSRIs } \\
\hline Kuiken SD, et al. [47] & $\begin{array}{l}\text { Fluoxetine }(n=19) \\
20 \mathrm{mg} / \mathrm{d} \text { for } 6 \mathrm{wk} \\
\operatorname{PBO}(n=21)\end{array}$ & $\begin{array}{l}\text { Mean (SD) threshold for pain and discomfort during rectal } \\
\text { distension: } \\
6 \mathrm{wk} \\
\text { ITT }(n=40): 28 \text { (3) } \mathrm{mm} \text { Hg with fluoxetine vs. } 29 \text { (3) } \mathrm{mm} \\
\text { Hg with PBO; no significant differences }\end{array}$ & Yes & $\begin{array}{c}\text { Fluoxetine: } \\
\text { - } n=2(10.5 \%) ; 2 \text { due to AEs } \\
\text { PBO: } \\
\text { - } n=4(19.0 \%) ; 4 \text { due to AEs }\end{array}$ \\
\hline Tabas G, et al. [49] & $\begin{array}{c}\text { Paroxetine + HFD }(n=38) \\
\text { Initial dose: } 10 \mathrm{mg} / \mathrm{d} \\
\text { EOT: } 10 \mathrm{mg} / \mathrm{d}(23 \%) ; 20 \mathrm{mg} / \mathrm{d}(43 \%) ; 40 \\
\mathrm{mg} / \mathrm{d}(33 \%) \\
\text { PBO + HFD }(n=43)\end{array}$ & $\begin{array}{l}\text { Percentage of patients with improvement in overall } \\
\text { well-being at } 12 \mathrm{wk} \\
63.3 \% \text { with paroxetine vs. } 26.3 \% \mathrm{PBO} ; p=0.01\end{array}$ & Yes & $\begin{array}{c}\text { Paroxetine: } \\
\text { - } n=8(21.1 \%) ; 4 \text { due to AEs } \\
\text { PBO: } \\
\text { - } n=7(16.3 \%) ; 4 \text { due to AEs }\end{array}$ \\
\hline Vahedi H, et al. [45] & $\begin{array}{l}\text { Fluoxetine }(n=22) \\
20 \mathrm{mg} / \mathrm{d} \text { for } 12 \mathrm{wk} \\
\text { PBO }(n=22)\end{array}$ & $\begin{array}{c}\text { Frequency of } 5 \text { abdominal symptoms (abdominal } \\
\text { discomfort, bloating, hard stool consistency, frequency of } \\
\text { bowel movement }<3 \text { times/wk, change in bowel habit): } \\
\text { ITT ( } n=44 \text { ) } \\
4 \text { wk: all symptoms less frequent with fluoxetine vs. PBO; } \\
p<0.05 \text { for all } \\
12 \text { wk: differences between treatments sustained }\end{array}$ & Yes & $\begin{array}{cc} & \text { Fluoxetine: } \\
\text { - } & \text { NR; } 35 \text { AEs reported } \\
\text { PBO: } \\
\text { - } & \text { NR; } 19 \text { AEs reported }\end{array}$ \\
\hline Tack J, et al. [46] & $\begin{array}{c}\text { Citalopram }(n=11) \\
\text { Initial dose: } 20 \mathrm{mg} / \mathrm{d} \text {, first } 3 \mathrm{wk} \\
\text { Increased to } 40 \mathrm{mg} / \mathrm{d} \text {, second } 3 \mathrm{wk} \\
\text { PBO }(n=12)\end{array}$ & $\begin{array}{c}\text { Mean (SD) number of days with reduction in overall } \\
\text { symptom severity (secondary endpoint) } \\
\text { ITT }(n=23) \text { First } 3 \text { wk: } \\
5.7 \text { (0.7) with citalopram vs. } 7.7 \text { (0.4) PBO; } p<0.05 \\
\text { Second } 3 \text { wk: } \\
5.0 \text { (0.8) with citalopram vs. } 7.3 \text { (0.5) PBO; } p<0.05\end{array}$ & Yes & $\begin{array}{c}\text { Citalopram: } \\
\text { - } n=1(9.1 \%) \text {, due to AEs } \\
\text { PBO: } \\
\text { - } n=1(8.3 \%) \text {, due to AEs }\end{array}$ \\
\hline Talley NJ, et al. [35] & $\begin{array}{c}\text { Citalopram }(n=17) \\
\text { Initial dose: } 20 \mathrm{mg} / \mathrm{d} \\
\text { Increased to } 40 \mathrm{mg} / \mathrm{d} \text { after } 2 \mathrm{wk} \\
\text { PBO }(n=16)\end{array}$ & $\begin{array}{l}\text { Patients achieving adequate relief of IBS symptoms at last } \\
\text { wk of tx (up to } 12 \mathrm{wk}): \\
\qquad \begin{array}{l}\text { ITT }(n=33): 69.2 \% \text { with citalopram vs. } 69.2 \% \text { PBO; } \\
p=0.80\end{array}\end{array}$ & Yes & $\begin{array}{c}\text { Citalopram: } \\
\text { - } n=5(29.4 \%) \text {; due to AEs NR } \\
\text { PBO: } \\
\text { - } n=3(18.8 \%) ; \text { due to AEs NR }\end{array}$ \\
\hline
\end{tabular}


Table 1. Cont.

\begin{tabular}{|c|c|c|c|c|}
\hline $\begin{array}{l}\text { Study Design and } \\
\text { Patient Population }\end{array}$ & Treatment(s) & Key Endpoint ${ }^{b}$ & AEs Reported & Discontinuations \\
\hline Masand PS, et al. [50] & $\begin{array}{c}\text { Paroxetine }(n=36) \\
\text { Initial dose: } 12.5 \mathrm{mg} \\
\text { Increased biweekly }(12.5-\mathrm{mg} / \mathrm{d} \\
\text { increments) to } 50 \mathrm{mg} / \mathrm{d} \text { for } 12 \mathrm{wk} \\
\text { PBO }(n=36)\end{array}$ & $\begin{array}{c}\text { ITT ( } n=72 \text { a wk 12: } \\
\text { Change from baseline in composite pain score: }-2.8 \text { with } \\
\text { paroxetine vs. }-1.9 \text { PBO; } p=0.82 \\
\text { CGI-improvement (score, } 1 \text { or } 2): 69.4 \%(25 / 36) \text { with } \\
\text { paroxetine vs. } 16.7 \% \text { (6/36) PBO; } p<0.01 \text { (secondary } \\
\text { endpoint) } \\
\text { CGI-severity ( } \geq 1 \text {-point reduction from baseline): } 58.3 \% \\
\text { (21/36) with paroxetine vs. } 27.8 \% \text { (10/36) PBO; } p<0.01 \\
\text { (secondary endpoint) }\end{array}$ & Yes & $\begin{array}{c}\text { Paroxetine } \\
\text { - } n=6(16.7 \%) ; 3 \text { due to AEs } \\
\text { PBO: } \\
\text { - } n=8(22.2 \%) ; 2 \text { due to AEs }\end{array}$ \\
\hline Ladabaum U, et al. [48] & $\begin{array}{l}\text { Citalopram }(n=27) \\
\text { Initial dose: } 20 \mathrm{mg} / \mathrm{d} \text { for } 4 \mathrm{wk} \\
\text { Increased to } 40 \mathrm{mg} / \mathrm{d} \text { for } 4 \mathrm{wk} \\
\quad \text { PBO }(n=27)\end{array}$ & $\begin{array}{c}\text { Self-reported weekly "adequate relief" of IBS symptoms } \\
\text { during } \geq 3 \text { of the previous } 6 \text { wk: } \\
\text { ITT }(n=54): 44.4 \% \text { (12/27) with citalopram vs. } 55.6 \% \\
(15 / 27) \text { PBO; } p=0.59 \\
\text { OR for weekly response with citalopram vs. PBO: } 0.80 \\
\text { ( } 95 \% \text { CI, } 0.61-1.04) \\
\text { PP }(n=45) \text { : OR for weekly response with citalopram vs. } \\
\text { PBO: OR: } 0.91 \text { (95\% CI, } 0.69-1.20)\end{array}$ & Yes & $\begin{array}{c}\text { Citalopram: } \\
\text { - } n=7(25.9 \%) ; 7 \text { due to AEs } \\
\text { PBO: } \\
\text { - } n=2(7.4 \%) ; 1 \text { due to AE }\end{array}$ \\
\hline
\end{tabular}


Antidepressants used to treat patients with IBS include TCAs and SSRIs [51]. In a 2019 meta-analysis of data from 18 RCTs in patients with IBS, results showed that patients taking antidepressant therapy reported a lower percentage of no improvement compared with those taking placebo, and results were similar when patients were subcategorized as taking either TCAs or SSRIs (Figure 1) [12].

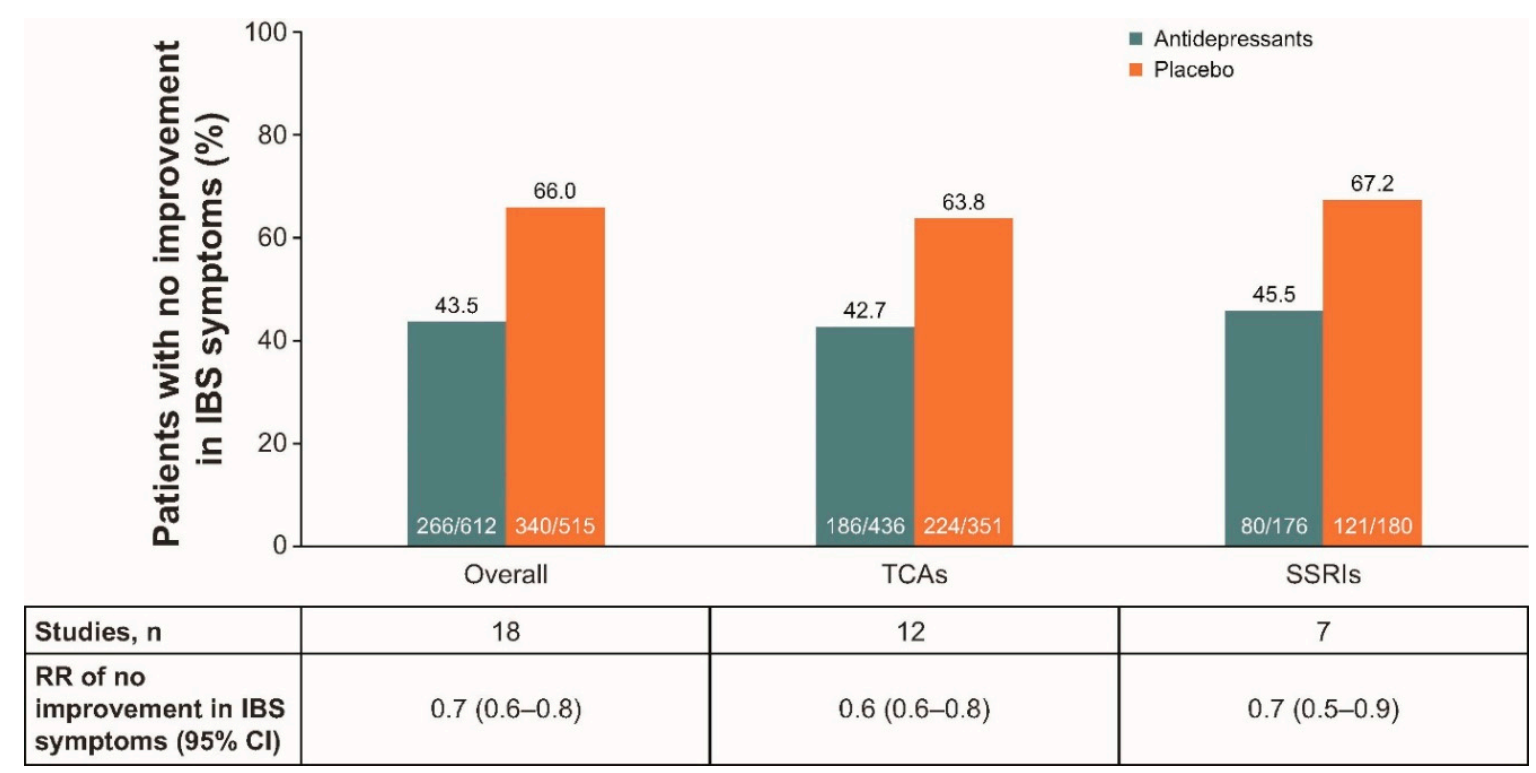

Figure 1. Efficacy of antidepressants for the treatment of IBS [12]. CI: confidence interval, IBS: irritable bowel syndrome, RR: relative risk, SSRI: selective serotonin reuptake inhibitor, TCA: tricyclic antidepressant.

In a meta-analysis of 12 RCTs (TCAs $(n=5)$, SSRIs $(n=6)$, TCAs and SSRIs $(n=1))$ published in 2015, evaluation of nine studies reporting global symptom relief showed that antidepressants improved global symptoms of IBS (relative risk (RR), 1.4, 95\% confidence interval (CI), 1.1-1.8) [18]. In a subgroup analysis, TCAs had a beneficial effect on improving global symptoms of IBS ( $n=5$ studies; RR, 1.4, 95\% CI, 1.1-1.7), whereas treatment with SSRIs did not have a significant effect on global symptoms ( $n=5$ studies; RR, 1.4, 95\% CI, 0.8-2.3) [18]. However, the five SSRI studies included three different medications (paroxetine, citalopram, and fluoxetine). In an analysis of abdominal pain, data from three studies (TCAs $(n=1)$, SSRIs $(n=3))$ indicated that antidepressants did not significantly improve this symptom (mean difference, $-8.9,95 \% \mathrm{CI},-19.7$ to 2.0 ) [18].

\section{Adverse Events with Antidepressant Therapy}

A 2019 systematic review and meta-analysis acknowledged that adverse events (AEs) were poorly reported in trials of antidepressants in patients with IBS [12]. A pooled analysis of data from the eight studies that reported AEs showed the incidence of AEs was significantly greater in patients treated with antidepressants than in those who received placebo ( $36.4 \%$ (83 out of 228 ) vs. $21.1 \%$ (47 out of 223); RR, 1.6, 95\% CI, 1.2-2.0), with a number needed to harm of 8.5 (95\% CI, 5-21) [12]. No serious AEs were reported. Of the eight studies that used TCAs, six showed that a significantly greater number of AEs occurred with TCAs compared with placebo (RR, 1.6; 95\% CI, 1.2-2.1) [12]. However, AE data were incompletely reported by many of the RCTs.

Among ten individual trials of antidepressants for the treatment of IBS that reported data for TCAs, five reported higher discontinuation rates with a TCA versus placebo, with the highest percentage of discontinuations associated with administration of imipramine (Table 1) [33,35,37,38,40]. Similarly, discontinuations due to AEs were greater among patients treated with TCAs compared with placebo 
(Table 1) [33,36-38,40]. Although not consistently reported, commonly reported AEs of TCAs have been drowsiness (range, 16-24\%), dry mouth (12-48\%), and fatigue (6-15\%) [33,34,37,40,41].

In a meta-analysis of 12 RCTs, two studies examined the occurrence of individual AEs with SSRIs; in these two studies the pooled RR of patients experiencing headache, poor sleep, anxiety, and nausea were 0.8 (95\% CI, 0.3-2.2), 1.0 (95\% CI, 0.4-2.5), 2.0 (95\% CI, 0.5-7.6), and 1.0 (95\% CI, 0.4-3.0), respectively [18]. For SSRIs, the percentages of patients experiencing individual AEs were reported in two studies $[45,50]$. In a study of 72 patients receiving paroxetine or placebo, the most commonly reported AEs were drowsiness ( $36.1 \%$ vs. $25.0 \%$, respectively), dry mouth $(27.7 \%$ vs. $16.6 \%)$, sexual dysfunction (female, $25.8 \%$ vs. $12.5 \%$; male, $20.0 \%$ vs. $0 \%$ ), poor sleep ( $16.6 \%$ vs. $13.8 \%$ ), and nightmares/vivid dreams (16.6\% vs. $13.8 \%$ ) [50]. In a study of 44 patients receiving fluoxetine or placebo, the most common AEs in the fluoxetine group were anorexia ( $22.7 \%$ vs. $4.5 \%$, respectively) and headache ( $22.7 \%$ vs. $18.2 \%)$ [45].

\section{Methodologic Considerations for Evaluating Antidepressant Data in IBS Clinical Studies}

\subsection{Sample Size}

Multiple methodologic characteristics of clinical trials of antidepressant therapies for IBS were systematically assessed (Figure 2).

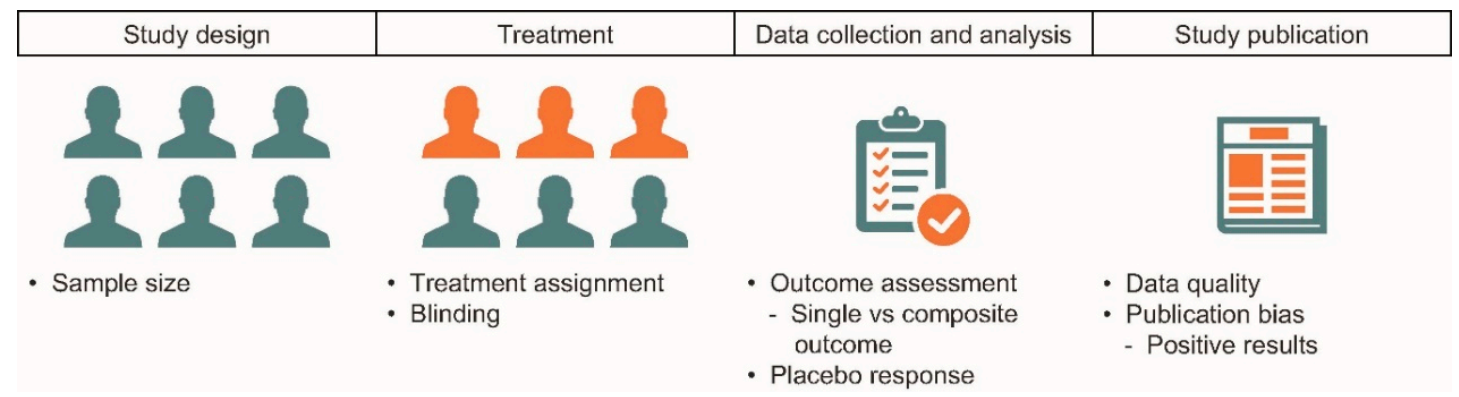

Figure 2. Methodologic characteristics assessed for clinical studies of antidepressant treatment in patients with irritable bowel syndrome.

The pooled mean number of patients randomly assigned to any antidepressant treatment arm in Table 1 was 35 (range, 11-144; median, 27), indicating a small sample size across the various published studies [33-50]. Inadequate power in clinical studies of antidepressants, due to insufficient sample size, may overestimate the desired effects of antidepressants relative to a control therapy [52]. A 2013 meta-epidemiologic study showed that when RCTs were stratified by sample size, treatment effect estimates were significantly larger in smaller trials than in the largest trials [53]. As the sample size increases, the variance in the results (as well as the placebo effect) converges. Thus, results from smaller studies have larger CIs and overestimate the treatment effect, so they should be interpreted with caution [53].

\subsection{Pooling of Data on Different Classes of Antidepressants}

There are various classes of antidepressants, and even drugs within the same class have dramatic differences in efficacy and AE profiles. This analysis included six antidepressants from the TCA class (desipramine, trimipramine, amitriptyline, doxepin, imipramine, and nortriptyline) and three from the SSRI class (fluoxetine, paroxetine, and citalopram; Table 1). The validity of pooling data for different antidepressants may be similar to pooling data from various biologics. For example, it would not be appropriate to pool data within or across the various classes of biologic agents to obtain a clinically relevant point estimate of the efficacy of biologic therapy in inflammatory bowel disease. A similar situation applies to antidepressants in IBS because pooling data from various classes, or data for drugs 
within the same class that have significantly different effects, does not necessarily provide a clear picture for healthcare providers or patients.

\subsection{Blinding}

Antidepressants used in IBS trials were already available on the market; hence, patient consent forms are required to clearly state the known AEs of the medication(s) being studied. These disclosures educate the participants about potential AEs of the drug and compromise blinding when the participant experiences such AEs. As a potential solution for this issue, Greenberg and Fisher [54] suggested the use of an "active placebo" such as atropine, which would exhibit some of the same AEs as TCAs. However, such an intervention has never been implemented in trials assessing patients with IBS. In addition, placebo tablets may have a different color, taste, and size if not matched exactly to the trial drug, which may lead to inadvertent unblinding, and care should be taken in selecting excipient compounds that are inert [55].

The most common TCA medications studied for IBS are amitriptyline, desipramine, doxepin, and nortriptyline. These medications have a generally similar AE profile that is well known to healthcare providers and the public and includes dry mouth, drowsiness, dizziness, fatigue, blurred vision, tinnitus, constipation, weight changes, increased perspiration, alterations in libido, and trouble urinating. Among the SSRIs, the most commonly studied medications are citalopram, fluoxetine, and paroxetine, with known AEs of dry mouth, fatigue/somnolence, and difficulty concentrating. Because these are common and well-known AEs, it remains questionable whether patients or investigators are truly blinded to which patients are receiving study drug or placebo in RCTs. These AEs typically do not occur to the same extent in patients receiving placebo, thus increasing the potential for bias [54]. The limitations of blinding were confirmed in a study in which a blinded evaluator, when provided $\mathrm{AE}$ profiles from a clinical trial (of etoperidone, a trazodone-like prospective antidepressant), correctly guessed treatment assignment for $72.7 \%$ of 22 patients receiving an antidepressant and $66.7 \%$ of 12 patients receiving placebo [56]. Similarly, if patients believe they are receiving active drug as part of a double-blind study, this knowledge theoretically will affect success rates [54]. In trials evaluating antidepressants, there was a substantial imbalance of AEs, with a predominance in the trial drugs versus placebo (36.4\% [83/228] vs. $21.1 \%$ [47/223], respectively) [12], which may have predisposed the studies to unblinding. When evaluating individual studies for the quality of blinding of participants, nine studies were deemed to be high risk due to a larger percentage of patients experiencing AEs in the antidepressant groups (Table 2). 
Table 2. Summary of bias risk in clinical studies of antidepressants in irritable bowel syndrome.

\begin{tabular}{|c|c|c|c|c|c|c|c|c|}
\hline Study & $\begin{array}{c}\text { Random Sequence } \\
\text { Generation }\end{array}$ & $\begin{array}{c}\text { Allocation } \\
\text { Concealment }\end{array}$ & $\begin{array}{l}\text { Blinding of } \\
\text { Participants }\end{array}$ & $\begin{array}{l}\text { Blinding of Outcome } \\
\text { Assessment }\end{array}$ & $\begin{array}{l}\text { Incomplete } \\
\text { Outcome Data }\end{array}$ & $\begin{array}{l}\text { Selective } \\
\text { Reporting }\end{array}$ & $\begin{array}{c}\text { Rate of } \\
\text { Discontinuations }\end{array}$ & $\begin{array}{l}\text { Overall } \\
\text { Quality }\end{array}$ \\
\hline \multicolumn{9}{|c|}{ TCAs } \\
\hline Heefner JD, et al. [38] & Unclear risk & Unclear risk & High risk & High risk & High risk & Unclear risk & High risk & Poor quality \\
\hline Myren J, et al. [39] & Unclear risk & Unclear risk & Unclear risk & Unclear risk & Low risk & Unclear risk & Unclear risk & Fair quality \\
\hline Nigam P, et al. [41] & Unclear risk & Unclear risk & High risk & Unclear risk & High risk & Unclear risk & Unclear risk & Poor quality \\
\hline Boerner D [44] & Unclear risk & Unclear risk & High risk & Unclear risk & High risk & Unclear risk & Unclear risk & Poor quality \\
\hline Bergmann ML, et al. [43] & Unclear risk & Unclear risk & Unclear risk & Unclear risk & Low risk & Unclear risk & Unclear risk & Fair quality \\
\hline Vij JG, et al. [40] & Low risk & Unclear risk & High risk & Low risk & High risk & Unclear risk & High risk & Poor quality \\
\hline Drossman DA, et al. [33] & Low risk & High risk & High risk & Low risk & High risk & Unclear risk & High risk & Poor quality \\
\hline Talley NJ, et al. [35] & Low risk & Low risk & High risk & Low risk & High risk & Unclear risk & High risk & Poor quality \\
\hline Vahedi $\mathrm{H}$, et al. [34] & Low risk & Low risk & Low risk & Low risk & High risk & Unclear risk & Low risk & Fair quality \\
\hline Abdul-Baki H, et al. [36] & Low risk & Low risk & High risk & Unclear risk & High risk & Unclear risk & High risk & Poor quality \\
\hline Ghadir MR, et al. [42] & Unclear risk & High risk & Unclear risk & High risk & Low risk & Unclear risk & High risk & Poor quality \\
\hline Agger JL, et al. [37] & Low risk & Low risk & High risk & Unclear risk & Low risk & Low risk & Low risk & Fair quality \\
\hline \multicolumn{9}{|c|}{ SSRIs } \\
\hline Kuiken SD, et al. [47] & Low risk & Low risk & Low risk & Unclear risk & High risk & Unclear risk & Low risk & Fair quality \\
\hline Tabas G, et al. [49] & Low risk & Low risk & Low risk & Low risk & High risk & Unclear risk & Low risk & Fair quality \\
\hline Vahedi H, et al. [45] & Low risk & Low risk & High risk & Low risk & Low risk & Unclear risk & Low risk & Fair quality \\
\hline Tack J, et al. [46] & Unclear risk & Unclear risk & Unclear risk & Unclear risk & Low risk & Unclear risk & Low risk & Fair quality \\
\hline Talley NJ, et al. [35] & Low risk & Low risk & Low risk & Low risk & Low risk & Unclear risk & Low risk & Good quality \\
\hline Masand P, et al. [50] & Unclear risk & Unclear risk & Low risk & Unclear risk & High risk & Unclear risk & Low risk & Fair quality \\
\hline Ladabaum U, et al. [48] & Unclear risk & Low risk & Unclear risk & Low risk & Low risk & Low risk & Unclear risk & Fair quality \\
\hline
\end{tabular}

SSRI: selective serotonin reuptake inhibitor, TCA: tricyclic antidepressant. 


\subsection{Overall Risk of Bias}

As outlined above, two authors (S.J.O. and W.T.) independently evaluated the risk for bias using the Cochrane Risk of Bias Tool for Randomized Controlled Trials, with any disagreements settled by discussion and achieving consensus of all three authors. Studies judged to be high risk in two or more categories were deemed to be poor quality, studies with only one category of high risk were deemed to be fair quality, and those without high risk in any category were deemed to be good quality. Eight of the 12 TCA trials were found to be of poor quality, and one of the seven SSRI trials was shown to be of good quality (Table 2) [33-50].

The relatively poor quality of the RCTs of antidepressants in patients with IBS further underscores the need for healthcare providers, patients, and authors of treatment guidelines for IBS to assess the results of these trials and strengthen treatment recommendations to use caution with these agents.

\subsection{Placebo Rate}

The overall placebo response also has been documented in clinical studies of IBS. A meta-analysis of 73 RCTs in IBS $(n=8364)$ reported a pooled placebo response rate of $37.5 \%$ [57]. Our analysis of the 18 studies summarized in Table 1 showed that the overall placebo response rate in the positive antidepressant studies $(20.8 \%)$ was less than half of that in the negative studies $(45.7 \% ; p<0.0001)$. The $20.8 \%$ placebo response rate in positive antidepressant studies is unusually low, compared with the $37.5 \%$ placebo response rate reported for all IBS studies [57]. The difference in placebo response rates may be secondary to the blinding bias risk mentioned previously and may play an important role in the significance of the positive studies. In addition, as alluded to by Tack et al., patient characteristics such as the prevalence of psychiatric comorbidities as well as the duration and stability of IBS symptoms may have played a role in varying the placebo rates [46]. In the meta-analysis of $73 \mathrm{RCTs}$, other factors that increased the placebo effect included reporting of study outcomes by the healthcare provider as opposed to patient reporting $(p=0.005)$ and shorter trial duration (i.e., $1-4$ weeks vs. $>8$ weeks; $p=0.004$ ) [57]. All of these flaws could potentially be minimized by designing a large, multicenter trial with common inclusion and exclusion criteria.

\subsection{Outcome Assessment}

Generally, the primary endpoint in IBS trials is improvement in gastrointestinal (GI) symptoms, usually assessed by a composite score. Use of composite scores may create problems with the interpretation of clinical trials [52], especially given the heterogeneity in GI symptoms associated with IBS [1] or in any other condition in which symptomology may vary among patients [58,59]. Comparison of composite outcome scores as valid clinical endpoints has been debated given that the actual individual symptoms may vary in patients with the same composite score [59]. For example, a Hamilton Depression Rating Scale score of 8 can result from a score of 4 for depressed mood and 4 for feelings of guilt, or from a score of 2 for insomnia, 4 for work and interest, and 2 for anxiety. Thus, the composite score may be identical for a group of patients, but the actual difference in individual symptoms and severity may be better (or worse) for some individuals.

\subsection{Publication Bias}

Clinical studies of antidepressant therapies in IBS reveal evidence of publication bias along with significant heterogeneity between studies $\left(I^{2}=69 \%, p<0.001\right)$ and significant funnel plot asymmetry [12]. The issue of publication bias among antidepressant clinical trials has been subject to a prolonged debate. Turner and colleagues [60] examined reviews from the FDA for studies of antidepressant agents; they found that approximately one-third (31\%) of the 74 registered studies had not been published. They also found that whether a study was published was strongly predicted by the outcome: 37 studies with positive results were published, whereas only one positive study was not published. In contrast, of the studies that were viewed as having negative results, only three 
studies were published, 22 studies were not published, and 11 studies that were viewed by the FDA as having a negative outcome conveyed a positive outcome in the published literature. These data may explain the discrepancy between the published literature showing $94 \%$ positive results for the antidepressant trials conducted versus the FDA analysis showing 51\% positivity [60]. Further, de Vries and associates [61] reported that $41.1 \%$ of studies describing negative results were published as part of pooled analyses, effectively "hiding" them, while $96.3 \%$ of studies with positive results were published as independent articles.

It should be noted that, during the FDA regulatory approval process, pharmaceutical companies are obligated to report available data to authorities, regardless of the publication status of a particular agent for a proposed indication. The same situation does not apply when agents are being studied for other disease states without plans for seeking marketing approval in the potential new treatment area (e.g., antidepressants in IBS). Hence, the potential for publication bias in clinical studies of antidepressants [60] for use with conditions other than depression (such as IBS) may be far greater. However, as some of these trials may not be registered, the extent of publication bias may not be fully determined.

\subsection{Fragility Index}

In the age of frequentist analysis with a standardized threshold $p$ value of 0.05 , the fragility index has been used to assess the strength of RCTs [62]. The fragility index is defined as the number of "non-events" that would need to change to "events" for the $p$ value to become $\geq 0.05$ using Fisher's exact test $[62,63]$. This number represents the number of events the trial relies on for statistical significance; thus, a higher index signifies a stronger study. When considering the RCT data for antidepressants in IBS [23,33-50], the calculation of fragility index values showed that eight $(66.7 \%)$ of the 12 TCA studies and three (42.9\%) of the seven SSRI studies had a fragility index of 0 (Table 3$)$.

Table 3. Fragility index for clinical studies of antidepressants in irritable bowel syndrome.

\begin{tabular}{ccc}
\hline Study & Fragility Index & Placebo Response Rate, $\%(n / n)$ \\
\hline Teefner JD, et al. [38] & 0 & \\
Myren J, et al. [39] & 0 & $45.5(10 / 22)$ \\
Nigam P, et al. [41] & 2 & $67.7(21 / 31)$ \\
Boerner D. [12,44] & 0 & $0.0(0 / 21)$ \\
Bergmann ML, et al. [23,43] & 5 & $53.7(22 / 41)$ \\
Vij JG, et al. [40] & 0 & $12.5(2 / 16)$ \\
Drossman DA, et al. [33] & 0 & $20.0(5 / 25)$ \\
Vahedi H, et al. [23,34] & 0 & $40.9(27 / 66)$ \\
Talley NJ, et al. [12,35] & 0 & $40.7(11 / 27)$ \\
Abdul-Baki H, et al. [36] & 0 & $68.8(11 / 16)$ \\
Ghadir MR, et al. [42] & 5 & $25.0(12 / 48)$ \\
Agger JL, et al. [37] & 6 & $16.7(4 / 24)$ \\
\hline Kuiken SD, et al. [47] & SSRIs & $23.3(14 / 60)$ \\
Tabas G, et al. [12,49] & 0 & $42.9(9 / 21)$ \\
Vahedi H, et al. [12,45] & 1 & $21.7(10 / 46)$ \\
Tack J, et al. [12,46] & 6 & $13.6(3 / 22)$ \\
Talley NJ, et al. [12,35] & 1 & $8.3(1 / 12)$ \\
Masand, et al. [50] & 0 & $68.8(11 / 16)$ \\
Ladabaum U, et al. [48] & 2 & $27.8(10 / 36)$ \\
\hline
\end{tabular}

SSRI: selective serotonin reuptake inhibitor; TCA: tricyclic antidepressant. 
The maximum fragility index was 6 for both TCA and SSRI studies, and the median (mean) fragility index of TCA and SSRI trials was 0 (1.5) and 1 (1.4), respectively. These results show that, on average, individual studies relied on only a small number of events for significance to be achieved. A high fragility index is moderately correlated with larger studies [62], and thus larger trials are needed to provide stronger evidence for the effectiveness of antidepressants in IBS.

\subsection{Primary Outcome of Interest}

Studies of IBS published before the 2012 guidance from the FDA regarding trial study design and outcomes for assessing the efficacy of agents for the treatment of IBS-D or IBS-C [64] used a variety of composite endpoints, such as patient-reported improvement in global IBS symptoms [12,18]. For example, "Subject Global Assessment of Relief," a primary endpoint widely used in many trials to assess efficacy, captures patients' subjective overall well-being based on symptoms of abdominal pain/discomfort and altered bowel habits, using a Likert scale based on the question, "Compared to the way you usually felt before entering the trial, how would you rate your relief of symptoms during the past week?" [64]. Given the high degree of subjectivity of current patient-reported outcomes, the FDA recommends against their use as a single primary outcome measure in IBS trials. Currently, the FDA recommends a composite endpoint that considers responders to be those patients achieving improvements in both abdominal pain intensity and stool consistency [64], which was only used in a few of the IBS trials that assessed antidepressants (Table 1).

Further, studies included in meta-analyses differ in patient populations and the specific therapy used, leading to heterogeneity in the data [12,18]. In the 18 studies summarized in Table 1, Rome II criteria was used most often (38.9\%; seven out of 18$)$, followed by no specific criteria (33.3\%; six out of 18$)$, Rome I ( $22.2 \%$; four out of 18$)$, and Rome III ( $5.6 \%$; one out of 18 ). IBS subtype majority was not listed in $55.6 \%$ (10 out of 18 ) of studies, $38.9 \%$ (seven out of 18 ) evaluated mainly IBS-D patients, and $5.6 \%$ (one out of 18 ) evaluated IBS-C patients. This heterogeneity makes comparisons across agents difficult and limits any global conclusions that can be drawn.

\section{Future Directions}

While none of the currently available FDA-approved drugs for IBS (alosetron, eluxadoline, linaclotide, lubiprostone, rifaximin, plecanatide, tegaserod, and tenapanor) and European Medicines Agency (EMA)-approved durgs for IBS (linaclotide and eluxadoline) possess antidepressant-like properties, GI societal guidelines support the use of antidepressants in the management of IBS, based on the available literature. All FDA and EMA-approved treatments for IBS have a robust sample size, with a mean sample size of 623 for alosetron, 1078 for eluxadoline, 717 for linaclotide, 455 for lubiprostone, 407 for rifaximin, 871 for plecanatide, 651 for tegaserod, and 629 for tenapanor $[7,65,66]$, whereas trials on antidepressants on average have a sample size of 63 [12]. A small sample size inadvertently leads to a variability in placebo rates, which may suggest a heterogeneity in the study populations between studies. Thus, it is difficult to make the generalizations needed to form a strong recommendation for a global audience for a very common disease such as IBS. In addition, most FDA-approved drugs were tested against FDA's rigorous composite endpoint, so future studies evaluating antidepressants should have a larger sample size and use the FDA's endpoint for efficacy. To preserve blinding in the setting of known side effects of antidepressants, the control arm of the studies should receive an active drug with a similar side-effect profile, such as anticholinergics or antispasmodics.

\section{Conclusions}

Clinical studies of antidepressants in IBS are limited by issues related to study design (e.g., sample size, blinding), data analysis (e.g., outcomes, placebo response), and data quality (e.g., selective reporting of AE profile, publication bias). Although studies support the efficacy of antidepressants in 
IBS, careful consideration of the limitations associated with clinical study designs with antidepressants, and thus their use, is warranted.

Author Contributions: All authors had access to the data and a role in writing the manuscript. A.R. conceptualized the study. S.J.O., W.T. and A.R. wrote the draft and edited the paper till the final version. W.T. performed the statistical analysis. A.R. and W.T. designed the methodology. S.J.O., W.T. and A.R. performed the required data collection. All authors agree to be personally accountable for their contributions and for ensuring that questions related to the accuracy or integrity of any part of the work are appropriately investigated, resolved, and documented in the literature. All authors have read and agreed to the published version of the manuscript.

Funding: This research received no external funding. The article processing fee was funded by Salix Pharmaceuticals.

Acknowledgments: Technical editorial assistance was provided by Mary Beth Moncrief, and Sophie Bolick, Synchrony Medical Communications, LLC, West Chester, PA, under the direction of the authors. Funding for this editorial assistance was provided by Salix Pharmaceuticals, Bridgewater, NJ, USA.

Conflicts of Interest: Sun Jung Oh and Will Takakura declare no conflict of interest. Ali Rezaie reports serving as a consultant for and receiving research grants from Salix Pharmaceuticals. The sponsor had no role in the design, execution, interpretation, or writing of the study, or in the decision to publish the results.

\section{References}

1. Lacy, B.E.; Mearin, F.; Chang, L.; Chey, W.D.; Lembo, A.J.; Simren, M.; Spiller, R. Bowel disorders. Gastroenterology 2016, 150, 1393-1407. [CrossRef]

2. Lovell, R.M.; Ford, A.C. Global prevalence of and risk factors for irritable bowel syndrome: A meta-analysis. Clin. Gastroenterol. Hepatol. 2012, 10, 712-721. [CrossRef]

3. Addante, R.; Naliboff, B.; Shih, W.; Presson, A.P.; Tillisch, K.; Mayer, E.A.; Chang, L. Predictors of health-related quality of life in irritable bowel syndrome patients compared with healthy individuals. J. Clin. Gastroenterol. 2019, 53, e142-e149. [CrossRef] [PubMed]

4. Frändemark, Å.; Tönblom, H.; Jakobsson, S.; Simrén, M. Work productivity and activity impairment in irritable bowel syndrome (IBS): A multifaceted problem. Am. J. Gastroenterol. 2018, 113, 1540-1549. [CrossRef] [PubMed]

5. Lee, C.; Doo, E.; Choi, J.M.; Jang, S.H.; Ryu, H.S.; Lee, J.Y.; Oh, J.H.; Park, J.H.; Kim, Y.S.; Brain-Gut Axis Research Group of Korean Society of Neurogastroenterology and Motility. The increased level of depression and anxiety in irritable bowel syndrome patients compared with healthy controls: Systematic review and meta-analysis. J. Neurogastroenterol. Motil. 2017, 23, 349-362. [CrossRef] [PubMed]

6. Shah, E.; Rezaie, A.; Riddle, M.; Pimentel, M. Psychological disorders in gastrointestinal disease: Epiphenomenon, cause or consequence? Ann. Gastroenterol. 2014, 27, 224-230.

7. Ford, A.C.; Moayyedi, P.; Chey, W.D.; Harris, L.A.; Lacy, B.E.; Saito, Y.A.; Quigley, M.M. American College of Gastroenterology monograph on management of irritable bowel syndrome. Am. J. Gastroenterol. 2018, 113, 1-18. [CrossRef]

8. Weinberg, D.S.; Smalley, W.; Heidelbaugh, J.J.; Sultan, S. American Gastroenterological Association Institute Guideline on the pharmacological management of irritable bowel syndrome. Gastroenterology 2014, 147, 1146-1148. [CrossRef]

9. Munjal, A.; Dedania, B.; Cash, B. Update on pharmacotherapy for irritable bowel syndrome. Curr. Gastroenterol. Rep. 2019, 21, 25. [CrossRef]

10. Drossman, D.A. Functional gastrointestinal disorders: History, pathophysiology, clinical features and Rome IV. Gastroenterology 2016, 150, 1262-1279. [CrossRef]

11. Holtmann, G.; Ford, A.C.; Talley, N.J. Pathophysiology of irritable bowl syndrome. Lancet Gastroenterol. Hepatol. 2016, 1, 133-146. [CrossRef]

12. Ford, A.C.; Lacy, B.E.; Harris, L.A.; Quigley, E.M.M.; Moayyedi, P. Effect of antidepressants and psychological therapies in irritable bowel syndrome: An updated systematic review and meta-analysis. Am. J. Gastroenterol. 2019, 114, 21-39. [CrossRef] [PubMed]

13. Xiong, N.; Duan, Y.; Wei, J.; Mewes, R.; Leonhart, R. Antidepressants vs. placebo for the treatment of functional gastrointestinal disorders in adults: A systematic review and meta-analysis. Front. Psychiatry 2018, 9, 659. [CrossRef] [PubMed] 
14. Kułak-Bejda, A.; Bejda, G.; Waszkiewicz, N. Antidepressants for irritable bowel syndrome-A systematic review. Pharmacol. Rep. 2017, 69, 1366-1379. [CrossRef] [PubMed]

15. Higgins, J.P.T.; Green, S. Cochrane Handbook for Systematic Reviews of Interventions; Wiley-Blackwell: Chichester, UK, 2008.

16. Rexwinkel, R.; Zeevenhooven, J.; van Etten-Jamaludin, F.S.; Benninga, M.A.; Tabbers, M.M. Side effects associated with pharmacotherapy for pediatric irritable bowel syndrome and functional abdominal pain —Not otherwise specified: A systematic review. Expert Opin. Drug Saf. 2019, 18, 111-125. [CrossRef]

17. Camilleri, M.; Boeckxstaens, G. Dietary and pharmacological treatment of abdominal pain in IBS. Gut 2017, 66, 966-974. [CrossRef]

18. Xie, C.; Tang, Y.; Wang, Y.; Yu, T.; Wang, Y.; Jiang, L.; Lin, L. Efficacy and safety of antidepressants for the treatment of irritable bowel syndrome: A meta-analysis. PLoS ONE 2015, 10, e0127815. [CrossRef]

19. Barker, W.R.; Glass, G.G. Which is better for IBS pain in women-Antispasmodics or antidepressants? J. Fam. Pract. 2015, 64, 734-735.

20. Ford, A.C.; Quigley, E.M.; Lacy, B.E.; Lembo, A.J.; Saito, Y.A.; Schiller, L.R.; Soffer, E.E.; Spiegel, B.M.; Moayyedi, P. Effect of antidepressants and psychological therapies, including hypnotherapy, in irritable bowel syndrome: Systematic review and meta-analysis. Am. J. Gastroenterol. 2014, 109, 1350-1365. [CrossRef]

21. Grover, M.; Camilleri, M. Effects on gastrointestinal functions and symptoms of serotonergic psychoactive agents used in functional gastrointestinal diseases. J. Gastroenterol. 2013, 48, 177-181. [CrossRef]

22. Shah, E.; Kim, S.; Chong, K.; Lembo, A.; Pimentel, M. Evaluation of harm in the pharmacotherapy of irritable bowel syndrome. Am. J. Med. 2012, 125, 381-393. [CrossRef] [PubMed]

23. Ruepert, L.; Quartero, A.O.; de Wit, N.J.; van der Heijden, G.J.; Rubin, G.; Muris, J.W.M. Bulking agents, antispasmodics and antidepressants for the treatment of irritable bowel syndrome. Cochrane Database Syst. Rev. 2011, 8, CD003460. [CrossRef] [PubMed]

24. Kaminski, A.; Kamper, A.; Thaler, K.; Chapman, A.; Gartlehner, G. Antidepressants for the treatment of abdominal pain-related functional gastrointestinal disorders in children and adolescents. Cochrane Database Syst. Rev. 2011, CD008013. [CrossRef] [PubMed]

25. Ford, A.C.; Talley, N.J.; Schoenfeld, P.S.; Quigley, E.M.; Moayyedi, P. Efficacy of antidepressants and psychological therapies in irritable bowel syndrome: Systematic review and meta-analysis. Gut 2009, 58, 367-378. [CrossRef]

26. Rahimi, R.; Nikfar, S.; Rezaie, A.; Abdollahi, M. Efficacy of tricyclic antidepressants in irritable bowel syndrome: A meta-analysis. World J. Gastroenterol. 2009, 15, 1548-1553. [CrossRef]

27. Pae, C.U.; Masand, P.S.; Ajwani, N.; Lee, C.; Patkar, A.A. Irritable bowel syndrome in psychiatric perspectives: A comprehensive review. Int. J. Clin. Pract. 2007, 61, 1708-1718. [CrossRef]

28. Tack, J.; Fried, M.; Houghton, L.A.; Spicak, J.; Fisher, G. Systematic review: The efficacy of treatments for irritable bowel syndrome-a European perspective. Aliment. Pharmacol. Ther. 2006, 24, 183-205. [CrossRef]

29. Bixquert-Jiménez, M.; Bixquert-Pla, L. Antidepressant treatment in functional digestive disorders. Gastroenterol. Hepatol. 2005, 28, 485-492. (In Spanish) [CrossRef]

30. Quartero, A.O.; Meiniche-Schmidt, V.; Muris, J.; Rubin, G.; de Wit, N. Bulking agents, antispasmodic and antidepressant medication for the treatment of irritable bowel syndrome (review). Cochrane Database Syst. Rev. 2005, 18, CD003460.

31. Lesbros-Pantoflickova, D.; Michetti, P.; Fried, M.; Beglinger, C.; Blum, A.L. Meta-analysis: The treatment of irritable bowel syndrome. Aliment. Pharmacol. Ther. 2004, 20, 1253-1269. [CrossRef]

32. Raine, R.; Haines, A.; Sensky, T.; Hutchings, A.; Larkin, K.; Black, N. Systematic review of mental health interventions for patients with common somatic symptoms: Can research evidence from secondary care be extrapolated to primary care? Br. Med. J. 2002, 325, 1-11. [CrossRef] [PubMed]

33. Drossman, D.A.; Toner, B.B.; Whitehead, W.E.; Diamant, N.E.; Dalton, C.B.; Duncan, S.; Emmott, S.; Proffitt, V.; Akman, D.; Frusciante, K.; et al. Cognitive-behavioral therapy versus education and desipramine versus placebo for moderate to severe functional bowel disorders. Gastroenterology 2003, 125, 19-31. [CrossRef]

34. Vahedi, H.; Merat, S.; Momtahen, S.; Kazzazi, A.S.; Ghaffari, N.; Olfati, G.; Malekzadeh, R. Clinical trial: The effect of amitriptyline in patients with diarrhoea-predominant irritable bowel syndrome. Aliment. Pharmacol. Ther. 2008, 27, 678-684. [CrossRef] 
35. Talley, N.J.; Kellow, J.E.; Boyce, P.; Tennant, C.; Huskic, S.; Jones, M. Antidepressant therapy (imipramine and citalopram) for irritable bowel syndrome: A double-blind, randomized, placebo-controlled trial. Dig. Dis. Sci. 2008, 53, 108-115. [CrossRef] [PubMed]

36. Abdul-Baki, H.; El Hajj, I.I.; Elzahabi, L.; Azar, C.; Aoun, E.; Skoury, A.; Chaar, H.; Sharara, A.I. A randomized controlled trial of imipramine in patients with irritable bowel syndrome. World J. Gastroenterol. 2009, 15, 3636-3642. [CrossRef]

37. Agger, J.L.; Schröder, A.; Gormsen, L.K.; Jensen, J.S.; Jensen, T.S.; Fink, P.K. Imipramine versus placebo for multiple functional somatic syndromes (STreSS-3): A double-blind, randomised study. Lancet Psychiatry 2017, 4, 378-388. [CrossRef]

38. Heefner, J.D.; Wilder, R.M.; Wilson, I.D. Irritable colon and depression. Psychosomatics 1978, 19, $540-547$. [CrossRef]

39. Myren, J.; Groth, H.; Larssen, S.E.; Larsen, S.; The Multicentre Study Group. The effect of trimipramine in patients with the irritable bowel syndrome. A double-blind study. Scand. J. Gastroenterol. 1982, 17, 871-875. [CrossRef] [PubMed]

40. Vij, J.C.; Jiloha, R.C.; Kumar, N.; Madhu, S.V.; Malika, V. Effect of antidepressant drug (doxepin) on irritable bowel syndrome patients. Indian J. Psychiatry 1991, 33, 243-246.

41. Nigam, P.; Kapoor, K.K.; Rastog, C.K.; Kumar, A.; Gupta, A.K. Different therapeutic regimens in irritable bowel syndrome. J. Assoc. Physicians India 1984, 32, 1041-1044.

42. Ghadir, M.R.; Habibinejad, H.; Heidari, A.; Vahedi, H. Doxepin is more effective than nortriptyline and placebo for the treatment of diarrhea-predominant irritable bowel syndrome: A randomized triple-blind placebo-controlled trial. Tehran Univ. Med. J. 2011, 69, 352-358.

43. Bergmann, M.; Heddergott, A.; Schlosser, T. Die therapie des colon irritabile mit trimipramin (Herphonal ${ }^{\circledR}$ )—Eine kontrollierte studie. Z. Klin. Med. 1991, 46, 1621-1628. (In German)

44. Boerner, D.; Eberhardt, R.; Metz, K.; Schick, E. Wirksamkeit und verträglichkeit eines antidepressivums beim colon irritabile. Article in German. Therapiewoche 1988, 38, 201-208.

45. Vahedi, H.; Merat, S.; Rashidioon, A.; Ghoddoosi, A.; Malekzadeh, R. The effect of fluoxetine in patients with pain and constipation-predominant irritable bowel syndrome: A double-blind randomized-controlled study. Aliment. Pharmacol. Ther. 2005, 22, 381-385. [CrossRef]

46. Tack, J.; Broekaert, D.; Fischler, B.; Van Oudenhove, L.; Gevers, A.M.; Janssens, J. A controlled crossover study of the selective serotonin reuptake inhibitor citalopram in irritable bowel syndrome. Gut 2006, 55, 1095-1103. [CrossRef]

47. Kuiken, S.D.; Tytgat, G.N.J.; Boeckxstaens, G.E.E. The selective serotonin reuptake inhibitor fluoxetine does not change rectal sensitivity and symptoms in patients with irritable bowel syndrome: A double blind, randomized, placebo-controlled study. Clin. Gastroenterol. Hepatol. 2003, 1, 219-228. [CrossRef]

48. Ladabaum, U.; Sharabidze, A.; Levin, T.R.; Zhao, W.K.; Chung, E.; Bacchetti, P.; Jin, C.; Grimes, B.; Pepin, C.J. Citalopram provides little or no benefit in nondepressed patients with irritable bowel syndrome. Clin. Gastroenterol. Hepatol. 2010, 8, 42-48. [CrossRef]

49. Tabas, G.; Beaves, M.; Wang, J.; Friday, P.; Mardini, H.; Arnold, G. Paroxetine to treat irritable bowel syndrome not responding to high-fiber diet: A double-blind, placebo-controlled trial. Am. J. Gastroenterol. 2004, 99, 914-920. [CrossRef]

50. Masand, P.S.; Pae, C.U.; Krulewicz, S.; Peindl, K.; Mannelli, P.; Varia, I.M.; Patkar, A.A. A double-blind, randomized, placebo-controlled trial of paroxetine controlled-release in irritable bowel syndrome. Psychosomatics 2009, 50, 78-86. [CrossRef]

51. Drossman, D.A. Beyond tricyclics: New ideas for treating patients with painful and refractory functional gastrointestinal symptoms. Am. J. Gastroenterol. 2009, 104, 2897-2902. [CrossRef]

52. Khan, A.; Mar, K.F.; Brown, W.A. The conundrum of depression clinical trials: One size does not fit all. Int. Clin. Psychopharmacol. 2018, 33, 239-248. [CrossRef] [PubMed]

53. Dechartres, A.; Trinquart, L.; Boutron, I.; Ravaud, P. Influence of trial sample size on treatment effect estimates: Meta-epidemiological study. BMJ 2013, 346, f2304. [CrossRef] [PubMed]

54. Greenberg, R.P.; Fisher, S. Suspended judgment. Seeing through the double-masked design: A commentary. Control Clin. Trials 1994, 15, 244-246. [CrossRef]

55. Wan, M.; Orlu-Gul, M.; Legay, H.; Tuleu, C. Blinding in pharmacological trials: The devil is in the details. Arch. Dis. Child. 2013, 98, 656-659. [CrossRef] 
56. White, K.; Kando, J.; Park, T.; Waternaux, C.; Brown, W.A. Side effects and the "blindability" of clinical drug trials. Am. J. Psychiatry 1992, 149, 1730-1731.

57. Ford, A.C.; Moayyedi, P. Meta-analysis: Factors affecting placebo response rate in the irritable bowel syndrome. Aliment. Pharmacol. Ther. 2010, 32, 144-158. [CrossRef]

58. Fried, E.I.; Nesse, R.M. The impact of individual depressive symptoms on impairment of psychosocial functioning. PLoS ONE 2014, 9, e90311. [CrossRef]

59. Fried, E.I.; Nesse, R.M. Depression sum-scores don't add up: Why analyzing specific depression symptoms is essential. BMC Med. 2015, 13, 72. [CrossRef]

60. Turner, E.H.; Matthews, A.M.; Linardatos, E.; Tell, R.A.; Rosenthal, R. Selective publication of antidepressant trials and its influence on apparent efficacy. N. Engl. J. Med. 2008, 358, 252-260. [CrossRef]

61. De Vries, Y.A.; Roest, A.M.; Turner, E.H.; de Jonge, P. Hiding negative trials by pooling them: A secondary analysis of pooled-trials publication bias in FDA-registered antidepressant trials. Psychol. Med. 2019, 49, 2020-2026. [CrossRef]

62. Ridgeon, E.E.; Young, P.J.; Bellomo, R.; Mucchetti, M.; Lembo, R.; Landoni, G. The fragility index in multicenter randomized controlled critical care trials. Crit. Care Med. 2016, 44, 1278-1284. [CrossRef] [PubMed]

63. Walsh, M.; Srinathan, S.K.; McAuley, D.F.; Mrkobrada, M.; Levine, O.; Ribic, C.; Molnar, A.O.; Dattani, N.D.; Burke, A.; Guyatt, G.; et al. The statistical significance of randomized controlled trial results is frequently fragile: A case for a Fragility Index. J. Clin. Epidemiol. 2014, 67, 622-628. [CrossRef]

64. Center for Drug Evaluation and Research, Food and Drug Administration, US Department of Health and Human Services. Guidance for Industry: Irritable Bowel Syndrome-Clinical Evaluation of Drugs for Treatment; Food and Drug Administration, MA, USA; 2012. Available online: http://www.fda.gov/downloads/Drugs/ Guidances/UCM205269.pdf (accessed on 31 March 2020).

65. Black, C.J.; Burr, N.E.; Ford, A.C. Relative efficacy of tegaserod in a systematic review and network meta-analysis of licensed therapies for irritable bowel syndrome with constipation. Clin. Gastroenterol. Hepatol. 2020, 18, 1238-1239.e1. [CrossRef] [PubMed]

66. Chey, W.D.; Lembo, A.J.; Rosenbaum, D.P. Efficacy of tenapanor in treating patients with irritable bowel syndrome with constipation: A 12-week, placebo-controlled phase 3 trial (T3MPO-1). Am. J. Gastroenterol. 2020, 115, 281-293. [CrossRef] [PubMed] 